\title{
Prevalence, Etiology, and Risk Factors of Mastitis in Dairy Cattle in Embu and Kajiado Counties, Kenya
}

\author{
Christine M. Mbindyo $\mathbb{D D}^{1}{ }^{1}$ George C. Gitao, ${ }^{1}$ and Charles M. Mulei ${ }^{2}$ \\ ${ }^{1}$ University of Nairobi, College of Agriculture and Veterinary Sciences, Department of Veterinary Pathology, \\ Microbiology and Parasitology, P.O. Box 29053-00625, Kangemi, Nairobi, Kenya \\ ${ }^{2}$ University of Nairobi, College of Agriculture and Veterinary Sciences, Department of Clinical Studies, P.O. Box 29053-00625, \\ Kangemi, Nairobi, Kenya \\ Correspondence should be addressed to Christine M. Mbindyo; cminoo@uonbi.ac.ke
}

Received 2 June 2020; Revised 21 June 2020; Accepted 4 July 2020; Published 4 August 2020

Academic Editor: Sumanta Nandi

Copyright ( $) 2020$ Christine M. Mbindyo et al. This is an open access article distributed under the Creative Commons Attribution License, which permits unrestricted use, distribution, and reproduction in any medium, provided the original work is properly cited.

\begin{abstract}
Bovine mastitis continues to be a leading cause of heavy economic losses in the dairy industry and a public health hazard globally. This cross-sectional study investigated the prevalence, etiologies of clinical and subclinical mastitis, and associated predisposing factors in Embu and Kajiado counties in Kenya. A semistructured questionnaire was administered to 154 smallholder dairy farmers to collect data on management practices, animal factors, and disease history. A total of 395 dairy cows were initially screened for subclinical mastitis using the California mastitis test (CMT), and milk samples were aseptically collected. Both CMT positive and CMT negative samples were analyzed using conventional bacteriological isolation and identification procedures. In the present study, the overall prevalence of mastitis based on CMT and clinical examination was 80\% (316/395), out of which 6.8\% (27/395) was clinical mastitis, while $73.1 \%$ (289/395) was subclinical mastitis. Based on culture, the overall prevalence of clinical and subclinical mastitis was $51.6 \%(815 / 1580), 74.4 \%(294 / 395)$, and $76.6 \%(118 / 154)$ at the quarter, cow, and farm level, respectively. From the 1574 milk samples analyzed by cultured, 1016 bacteria were yielded. The predominant bacteria were coagulase-negative Staphylococcus (CNS), 42.8\% (435/1016), and in decreasing order, Streptococcus species, 22.2\% (226/1016), Staphylococcus aureus, 15.7\% (160/1016), and Pseudomonas aeruginosa, 5.1\% (52/1016), and the least was Enterobacter species, $0.7 \%$ (7/1016), while $23.7 \%$ of the sample yielded no bacterial growth. Risk factor analysis revealed that milking mastitic cows last $(p=0.002)$, using a clean udder drying towel for each cow $(p=0.033)$ and previous history of mastitis $(p=0.046)$ were significantly associated with presence of mastitis. The current study has shown a relatively high prevalence of subclinical mastitis with CNS as predominant bacteria. Therefore, control measures are urgently warranted. Management factors such as milking mastitic cows last, using a clean towel for udder drying for each cow, and culling mastitic cows should be considered and included in the Kenyan mastitis control programs.
\end{abstract}

\section{Introduction}

Bovine mastitis remains one of the most critical diseases of dairy cows globally $[1,2]$. This disease is of particular concern, especially in Africa, including Kenya, where there is limited research on mastitis $[3,4]$. Apart from the substantial economic losses associated with the disease, mastitis has serious zoonotic potential and has been associated with the increasing development and the rapid emergence of multidrug resistance strains globally [5-8].
Mastitis, which is the inflammation of the udder and teats, exists in two primary forms: clinical and subclinical mastitis $[9,10]$. Clinical mastitis, which is less prevalent, is characterized by systemic signs in the cow and visible abnormalities in the udder and milk $[11,12]$. In contrast, subclinical mastitis is more common and results to reduced milk production without observable clinical signs or abnormalities in the udder or milk $[13,14]$. For this reason, subclinical mastitis is challenging to diagnose, persists longer in the herd, and is associated with higher losses compared to clinical mastitis [15]. 
A wide range of microbes have been documented as causative agents of mastitis globally [4, 12]. These include both contagious and environmental bacteria, in addition to fungi, algae, and viruses. Evidence-based studies have shown significant variation in the distribution of mastitis and mastitis-causing pathogens among countries, regions, and farms [16, 17]. These variations are influenced by farm management practices and regional environmental factors $[10,18]$.

Bacteria are the primary causes of mastitis, and more than 140 different pathogenic species have been reported [4]. Previously, studies had documented major pathogens of mastitis such as Staphylococcus aureus, Streptococcus agalactiae, and Coliforms [19, 20]. However, current studies by various scholars have reported a change of the causative agents of mastitis from the major pathogens to minor pathogens such as coagulase-negative Staphylococcus and other bacilli $[14,21-23]$. These reports have shown that these minor pathogens may be playing a significant role in the pathogenesis of mastitis and vary from herd to herd [24, 25]. Hence, this transition warrants a review of traditional control and preventive measures of the disease [23].

Prompt identification and understanding diversity of pathogens associated with mastitis is essential for effective prevention and control [26]. Several studies have reported that subclinical mastitis in the East African region is on the rise. These include studies by Abrahmsén and Persson [15] and discussed elsewhere by $[13,14,27]$. However, studies in Kenya on prevalence and risk factors to mastitis remain limited, while knowledge concerning mastitis pathogens remains scarce [28-30]. Moreover, there has been no comparison of these factors between pastoral and smallholder farming communities. This limitation of studies on mastitis in Kenya is a serious problem because the inability to correctly and accurately identify the pathogen leads to difficulty in selecting the appropriate pathogen-specific treatment or control measure to apply. Moreover, lack of proper identification of the causative agent of mastitis has led to the indiscriminate use of antibiotics, consequently increasing development, and the rapid emergence of multidrug resistance strains [31].

Furthermore, mastitis is of great concern in Kenya, especially in smallholder farms in major towns and environs, such as Kajiado and Embu [1]. In these regions, there is an increasing demand for milk and milk products to cater to the fast-growing human population $[32,33]$. Hence, there is an urgent need for extensive research on the status of mastitis and mastitis pathogens in Kenya in order to improve existing control measures and guide treatment. The current study investigated the prevalence, etiology of clinical and subclinical mastitis, and associated risk factors in dairy cows in Embu and Kajiado counties, Kenya.

\section{Materials and Methods}

2.1. Ethical Approval. The study was reviewed and approved by the University of Nairobi, Faculty of Veterinary Medicine Biosafety, Animal Use, Care, and Ethics Committee before initiation of the study (FVM/BAUEC/2018/157). To participate in the study, farmers were required to give informed consent verbally.

2.2. Study Sites. This cross-sectional study was conducted in two counties in Kenya, namely, Embu and Kajiado, between November 2018 and June 2019. In Embu County, the study was conducted in Runyenjes and Kyeni North and in Kajiado County, in Rongai, Ngong, and Kiserian regions (Figure 1).

The study areas broadly fall into two agroclimatic zones. The Kajiado County zone has a hot and humid tropical climate, while Embu is under the trimodal rainy and humid tropical climate. These two counties were purposefully selected based on the high populations of dairy cows in the regions and the increasing demand for cow milk due to the rapidly growing human population in the regions.

Embu County is a high potential area which consists of highlands and lowlands. This county lies between $37.7238^{\circ} \mathrm{E}$ and $0.6560^{\circ} \mathrm{S}$. It rises from about $515 \mathrm{~m}$ above sea level at the Tana River basin in the east to over $4570 \mathrm{~m}$ above the sea in the northwest which is part of Mt. Kenya. It covers an area of a population of 608,599 persons, most of whom are smallscale farmers. Kajiado County lies between $2.0981^{\circ} \mathrm{S}$ and $36.7820^{\circ} \mathrm{E}$. It covers $21,292.7 \mathrm{~km}$ area, and in 2019 , the human population was at $1,117,840$, and most of whom are traditional pastoralists. The county borders the capital city Nairobi to the west and Tanzania to the south [34].

2.3. Study Animals. The study animals were lactating dairy cows of exotic and crosses (mainly crossbreed of exotic and the zebus, a local breed) origin. The cows were in different parities, and stages of lactation from smallholder farmers were randomly selected from the two counties. All cows from Embu were intensively kept, whereas, in Kajiado, animals were semi-intensively and intensively reared.

2.4. Study Designs and Sample Size Determination. A crosssectional design was used in this study. The sample size was calculated using the formula as given by Thrusfield [35]; $n=$ $\left(1.96^{2}\right)\left(P_{\exp }\right)\left(1-P_{\exp }\right) / d^{2}$ where $n$ is the sample size, 1.96 is the $Z$ statistic for a level of $95 \%$ confidence, $P_{\exp }$ is expected prevalence, and $d$ is the desired absolute precision, which is equal to $5 \%(0.05)$. With an expected prevalence of $54.2 \%$ [3], a sample size of 381 was obtained; however, 400 animals were sampled instead. A total of 154 available and willing farms owning (<10 cows) were included in the study.

2.5. Sampling Technique and Sampling Frame. Initially, Embu and Kajiado counties were purposively selected from the 47 counties in Kenya based on the high population of cows and the increasing demand for milk due to urbanization in these regions. In addition, the counties had different production systems where Kajiado consisted of both semi-intensive and intensive smallholder farmers while Embu consisted of exclusively intensive smallholder farmers. Farms were randomly selected from lists of farmers provided by the veterinary county officers from each of the counties. 

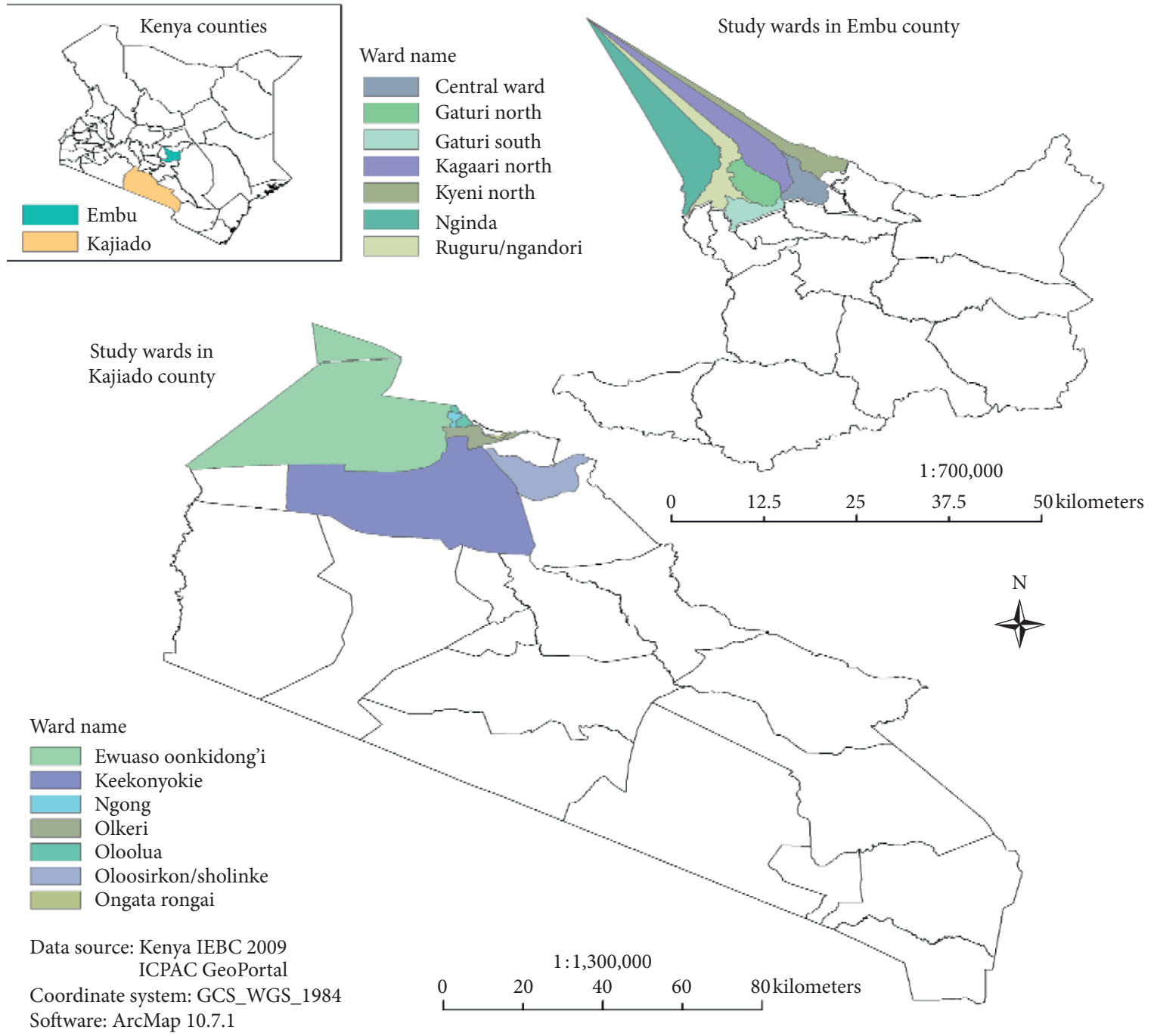

Figure 1: Map of the Embu and Kajiado showing the study sites.

For a farm to be included in the study, they had to have at least two lactating cows, and the farmer had to be willing to take part in the study. A total of 154 smallholder farms and 400 lactating dairy cows were recruited and sampled between November 2018 and June 2019. In each farm, two cows were randomly selected and sampled. In farms with more than two lactating cows, the remaining cows were randomly sampled, and a maximum of six lactating dairy cows were sampled in such farms. Data for five cows were removed from the study because they were incomplete.

2.6. Questionnaire Administration. During the farm visits, data were collected using a pretested semistructured questionnaire administered on each farm via personal interviews. The information collected included farm biodata and farm management practices such as production system (intensive or semi-intensive), housed with a roof (yes or no), floor type (concrete or earthen), bedding (yes or no), cleaning frequency (daily or weekly), proper milking techniques (yes or no), milking mastitic cow last (yes or no), washing of the udder before milking (yes or no), drying of the udder after washing (yes or no), udder towel for each cow (yes or no), routine testing for mastitis (yes or no), use of teat dips (yes or no), dry therapy (yes or no), and culling (yes or no). Cow factors were breed (cross or exotic), stage of lactation recorded in months (1-2) (3-6) (>7), parity $(1,2,3,4+)$, and history of mastitis (yes/no). All collected risk factors were compared to the occurrence of mastitis based on bacteriology results.

2.7. California Mastitis Testing and Sample Collection. At the farm, the California mastitis test (CMT) was carried out based on the guidelines described by Schalm [36] and NMC [37]. A total of 400 cows were screened, and milk samples were collected from each quarter. All udders and teats for each cow were physically examined. Detection of clinical mastitis was done by examining the udder and the teats for any inflammation, fever in the animals, and checking the milk's consistency for the presence of clots, blood, and flakes [11]. Following physical examination, screening for subclinical mastitis (SCM) using the California mastitis test (CMT) was done. The CMT results were interpreted 
subjectively as either negative, trace, $1+, 2+$, or $3+$, as described by NMC [37]. Based on the CMT, cows were considered positive for SCM if they had readings of $(1+, 2+$, $3+)$, whereas negative and trace were taken as negative. The cows were then grouped, and results were recorded as mastitic or nonmastitic. A cow was regarded as mastitis positive if at least one of the quarters was CMT positive. Milk samples were then collected from both CMT positive and negative cows. Briefly, before sampling, the udder was thoroughly washed with water and dried. After disinfecting the teats with $70 \%$ ethyl alcohol swabs, followed by stripping 4-5 streams of milk, 5-10 ml of milk was collected from each quarter aseptically and put in separate universal bottles held at a slightly horizontal position to avoid contamination from the udder [11,37]. The sample bottles were then appropriately sealed and labeled. Samples were refrigerated in iceboxes with cold packs and transported to the University of Nairobi, Department of Veterinary Pathology, Microbiology, and Parasitology Bacteriology Laboratory, for processing. The samples were cultured immediately or stored in the refrigerator at $4^{\circ} \mathrm{C}$ for a maximum of a day, awaiting culture.

2.8. Bacterial Isolation and Identification. All bacteriological examination was done at the bacteriology laboratory, according to standard methods described in the Laboratory Handbook on Bovine Mastitis [37]. The samples were first brought out of the fridge, left outside to warm up to room temperature $\left(24^{\circ} \mathrm{C}-26^{\circ} \mathrm{C}\right)$. Milk samples from five cows were eliminated from the study because they had missing data. Milk samples from 395 were analyzed. Briefly, a $0.01 \mathrm{ml}$ aliquot of each milk sample was aseptically streaked onto the surface of $5 \%$ sheep blood agar and MacConkey agar plates (Oxoid, England). The plates were incubated aerobically at $37^{\circ} \mathrm{C}$ for $18-24$ hours. After which, the colony morphology was read and recorded. The plates with no growth were further reincubated for up to 72 hours, after which they were concluded as no growth. Samples yielding more than one colony were grouped as mixed cultures. The distinct colonies were subcultured separately to obtain pure colonies by restreaking. Single colonies from respective isolates were then subcultured onto nutrient agar slants. The slants were stored at $4^{\circ} \mathrm{C}$ for further use. The bacterial cultures were initially studied morphologically, then microscopically, and later biochemical tests were used to determine the genus and species of pathogens in the sample.

Staphylococcus species were identified using growth characteristics, catalase test, tube coagulase testing, and mannitol salt agar (Oxoid, England). Streptococcus species were identified using the catalase test and growth characteristics on Edward's media (Oxoid, England) and within the group differentiation was done using the CAMP test. Gramnegative bacteria were identified using colony morphology and lactose fermentation on MacConkey, oxidase test, sugar fermentation, and IMViC tests: I for indole test, $\mathrm{M}$ for methyl red test, Vi for Voges-Proskauer test, and $\mathrm{C}$ for citrate utilization test (Oxoid England). A cow was considered mastitic positive if at least one quarter was positive for bacterial isolation.

2.9. Data Analysis. Data entry and management was done using Microsoft Excel 2016, while data analysis was done using STATA version15. Descriptive statistics were used to calculate the prevalence of clinical and subclinical mastitis. Prevalence was calculated as the proportion of sick over the total population analyzed. Univariate analysis was used to assess the association between the dependent variable (mastitis outcome based on bacterial isolation, $0=$ negative, $1=$ positive) and independent variables (risk factors). All variables with $p<0.05$ (5\%) were considered for a final model and analyzed using multivariable logistic regression. In this analysis, the statistical significance was set at $p<0.05$. The output of the model was presented as odds ratio and $95 \%$ confidence interval.

\section{Results}

3.1. Prevalence of Clinical and Subclinical Mastitis Based on California Mastitis Test and Culture in Study Areas. A total of 1580 quarters from 395 cows in 154 farms from the two counties were analyzed for mastitis in this study. The overall prevalence of mastitis based on CMT and clinical examination was $80 \%(316 / 395)$, of which $6.8 \%(27 / 395)$ were clinically sick and $73.1 \%$ (289/395) had subclinical mastitis. Within the counties, Embu reported a higher prevalence in both clinical mastitis and subclinical mastitis, with $8.4 \%$ (16/ 189 ) and $73.5 \%(139 / 189)$, respectively. Kajiado County reported $5.3 \%(11 / 206)$ in clinical mastitis and $72.8 \%(150 /$ 206) in subclinical mastitis. There was no significant difference between the means of the two counties based on CMT $(p>0.3)$.

Based on the bacterial isolation, the overall prevalence of mastitis in this study, at farm, cow, and quarter level, was $76.6 \%$ (118/154), 74.4\% (294/395), and 51.5\% (815/1580), respectively. Embu County reported higher prevalence at farm and cow level at 78.7\% (63/80) and 79.3\% (150/189), whereas Kajiado County had 74.3\% (55/74) and 69.9\% (144/ 206), respectively. Similarly, Embu County reported a higher prevalence of quarter-level mastitis, 60.1\% (455/756), as compared to Kajiado, which had $43.6 \%$ (360/824). There was a significant difference between the prevalence of mastitis at cow and quarter level within the two counties $(p<0.03$; $p<0.01)$.

3.2. Prevalence of Causative Bacteria of Mastitis in Embu and Kajiado Counties. Out of the 1580 quarters examined, 6 of them were blind and did not produce any milk. A total of 1574 quarters were cultured for bacterial isolation, which yielded a total of 1016 bacteria. 62\% of the samples had a single bacterium, while $37.9 \%$ were mixed culture. Overall, from both counties, the most prevalent bacteria were coagulase-negative Staphylococcus (CNS) and Streptococcus spp.; while Micrococcus spp. and Enterobacter spp. were the least recovered organisms (Table 1). Also, from the table, Micrococcus spp. and Streptococcus agalactiae were not 
TABLE 1: Summary table of the distribution of bacteria isolated from clinical and subclinical mastitis in Embu and Kajiado counties, Kenya.

\begin{tabular}{lccccc}
\hline \multirow{2}{*}{ Bacteria } & \multicolumn{2}{c}{ Clinical mastitis $(\%)$} & \multicolumn{2}{c}{ Subclinical mastitis (\%) } & $\begin{array}{c}\text { Total (\%) } \\
\text { Combined }\end{array}$ \\
& Embu County & Kajiado County & Embu County & Kajiado County & $42.8(435 / 1016)$ \\
Coagulase-negative Staphylococcus & $45.4(20 / 44)$ & $22.2(4 / 18)$ & $41.4(227 / 547)$ & $45.2(184 / 407)$ & $4.1(110 / 547)$ \\
Streptococcus spp. & $22.7(10 / 44)$ & $38.8(7 / 18)$ & $24.3(99 / 407)$ & $22.2(226 / 1016)$ \\
Streptococcus agalactiae & - & - & $0.1(1 / 547)$ & $0.7(3 / 407)$ & $0.4(4 / 1016)$ \\
Staphylococcus aureus & $13.6(6 / 44)$ & $22.2(4 / 18)$ & $13.8(76 / 547)$ & $18.1(74 / 407)$ & $15.7(160 / 1016)$ \\
Bacillus spp. & $9(4 / 44)$ & - & $10.6(58 / 547)$ & $3.6(15 / 407)$ & $7.6(77 / 1016)$ \\
Pseudomonas aeruginosa & $2.2(1 / 44)$ & - & $5.3(29 / 547)$ & $5.4(22 / 407)$ & $5.1(52 / 1016)$ \\
Escherichia coli & $6.8(3 / 44)$ & $5.5(1 / 18)$ & $4.2(23 / 547)$ & $1.2(5 / 407)$ & $3.1(32 / 1016)$ \\
Klebsiella spp. & - & $5.5(1 / 18)$ & $2(11 / 547)$ & $0.4(2 / 407)$ & $1.4(14 / 1016)$ \\
Micrococcus spp. & - & - & $1(6 / 547)$ & $0.7(3 / 407)$ & $0.9(9 / 1016)$ \\
Enterobacter spp. & - & $5.5(1 / 18)$ & $1(6 / 547)$ & - & $0.7(7 / 1016)$ \\
Total & $4.3(44 / 1016)$ & $1.7(18 / 1016)$ & $53.8(547 / 1016$ & $40(407 / 1016)$ & $100(1016 / 1016)$ \\
\hline
\end{tabular}

recovered from clinically sick quarters. However, on the other hand, all isolated bacteria were reported in subclinical mastitis. In this study, the mastitis-causing organisms frequently identified in the two counties were almost similar. In Embu County, CNS was the most prevalent bacteria isolated in clinical and subclinical mastitis followed by Streptococcus spp. and Staphylococcus aureus. In Kajiado County, however, Streptococcus spp. were the most prevalent bacteria in clinical mastitis, while in subclinical mastitis, CNS was reported highest (Table 1).

In this study, there was a significant difference, in the prevalence of Bacillus spp. and Escherichia coli recovered between the two counties $(p<0.05)$. Embu County reported a higher prevalence of Bacillus spp. and Escherichia coli compared to Kajiado. However, the other bacteria isolated from the two counties did not show any statistical significance differences in their prevalence (Table 2).

It is noteworthy that $23.7 \%(251 / 1058)$ of the clinical and CMT positive samples did not yield any bacterial growth.

3.3. Mastitis Risk Factors. Risk factors included management factors such as county, production system, housed, floor type, bedding, floor cleaning frequency, proper milking techniques, milking mastitic cows last, washing of the udder before milking, udder drying, udder drying towel for each cow, routine testing for mastitis using CMT, alcohol test, use of teat dips, dry therapy, and culling. Cow factors included stage of lactation, breed, history of mastitis, and parity. Table 3 represents a summary of the frequency of all variables considered in the study.

3.4. Logistic Regression of Risk Factors with the Occurrence of Mastitis. Several risk factors were considered for univariate logistic regression for the presence of mastitis as shown in Table 4. Among the risk factors analyzed, county, bedding, parity, milking mastitic cows last, udder drying towel for each cow, washing hands between milkings, use of teat dips, routine testing for mastitis, and history of mastitis were significantly associated with the presence of mastitis $(p<0.05)$. On the other hand, production system, housed, floor type, proper milking technique, cleaning frequency of the house, floor type, clean udder drying towel, dry cow therapy, culling, breed, and stage of lactation were not significantly associated with mastitis $(p>0.05)$.

All variables with $p<0.05(5 \%)$ in the initial univariate regression were included in the multivariable logistic regression analysis. Variables included were county, bedding, milking mastitic cows last, udder drying towel for each cow, washing hands between milkings, teat dips, routine testing for mastitis, parity, and history of mastitis. However, on controlling for confounding effect, parity and bedding were eliminated from the final analysis. The remaining seven variables were analyzed and revealed that milking the mastitic cows last $(p=0.002)$, clean udder drying towel for each cow $(p=0.033)$, and history of mastitis $(p=0.046)$ were significantly associated with the occurrence of mastitis $(p<0.05)$. County, testing for mastitis, use of teat dips, and washing hands between milkings were not statistically significant $(p>0.05)$. Accordingly, the likelihood of occurrence mastitis in dairy cows with a previous history of mastitis was 1.7 higher than in cows, which had no previous history of mastitis $(\mathrm{OR}=1.717$; 95\% CI: 1.061, 2.78). Similarly, there was 2.3 times more likelihood of mastitis occurrence in farms, which did not milk mastitic cows last compared to farms which did $(\mathrm{OR}=2.264$; 95\% CI: 1.645, 4.314). Farms, where each cow did not have its own udder drying towel, were 2.5 more likely to get mastitis than farms where each cow had its own udder towel $(\mathrm{OR}=2.491 ; 95 \% \mathrm{CI}$ : $1.188,3.154)$ as shown in Table 5.

\section{Discussion}

Knowledge on prevalence of mastitis, the microbial diversity, and risk factors associated with the disease development would greatly improve prevention and guide on treatment.

In the current study, the overall prevalence of mastitis reported was relatively high $(80 \%)$. These results were in line with findings in a previous study in Kenya by Ondiek and Kemboi [29], who reported a prevalence of $82.9 \%$. Similar studies by Abebe et al. [2] and Ndahetuye et al. [14] who reported a prevalence of $76 \%$ in Ethiopia and $76.2 \%$ in Rwanda, respectively, were in close agreement with our findings. However, this study's findings slightly differed with results by Tolosa et al. [38], 85\% in Ethiopia, and Abrahmsén and Persson [15], 86.2\% in Uganda. On the other hand, these 
TABLE 2: Effect of counties on the prevalence of mastitis pathogens.

\begin{tabular}{|c|c|c|c|}
\hline Bacteria & $\begin{array}{c}\text { Embu }(\%) \\
n=591\end{array}$ & $\begin{array}{c}\text { Kajiado (\%) } \\
n=425\end{array}$ & $\begin{array}{c}\text { Total }(\%) \\
n=1016\end{array}$ \\
\hline Coagulase-negative Staphylococcus & $41.7^{\mathrm{a}}(247 / 591)$ & $44.2^{\mathrm{a}}(188 / 425)$ & $42.8(435 / 1016)$ \\
\hline Streptococcus spp. & $20.3^{\mathrm{a}}(120 / 591)$ & $24.9^{\mathrm{a}}(106 / 425)$ & $22.2(226 / 1016)$ \\
\hline Streptococcus agalactiae & $0.1^{\mathrm{a}}(1 / 591)$ & $0.7^{\mathrm{a}}(3 / 425)$ & $0.4(4 / 1016)$ \\
\hline Staphylococcus aureus & $13.8^{\mathrm{a}}(82 / 591)$ & $18.3^{\mathrm{a}}(78 / 425)$ & $15.7(160 / 1016)$ \\
\hline Bacillus spp. & $10.4^{\mathrm{a}}(62 / 591)$ & $3.5^{\mathrm{b}}(15 / 425)$ & $7.6(77 / 1016)$ \\
\hline Pseudomonas aeruginosa & $5^{\mathrm{a}}(30 / 591)$ & $5.5^{\mathrm{a}}(22 / 425)$ & $5.1(52 / 1016)$ \\
\hline Escherichia coli & $4.3^{\mathrm{a}}(26 / 591)$ & $1.4^{\mathrm{b}}(6 / 425)$ & $3.1(32 / 1016)$ \\
\hline Klebsiella spp. & $1.8^{\mathrm{a}}(11 / 591)$ & $0.7^{\mathrm{a}}(3 / 425)$ & $1.4(14 / 1016)$ \\
\hline Micrococcus spp. & $1^{a}(6 / 591)$ & $0.7^{\mathrm{a}}(3 / 425)$ & $0.9(9 / 1016)$ \\
\hline Enterobacter spp. & $1^{\mathrm{a}}(6 / 591)$ & $0.2^{\mathrm{a}}(1 / 425)$ & $0.7(7 / 1016)$ \\
\hline
\end{tabular}

$n=$ total number of bacterial isolates. Different superscript letters on the same row denote a subset of county category whose proportions differ significantly within the row $(p<0.05)$. Similar superscript letters on the same row denote a subset of county category whose proportions do not differ significantly within the row $(p>0.05)$.

results were higher than reports by Mureithi and Njuguna [28] and Gitau et al. [3], 54.2\%, in different parts of Kenya. The inconsistencies in prevalence in these studies could be due to differences in management, environmental, epidemiological, and breed factors [10]. The high prevalence reported in this study could be indicative of inadequate monitoring, control, and prevention measures of mastitis in the study areas.

The present study reported clinical mastitis of $6.8 \%$. These findings were closely related to what was reported by Sarba and Tola [39], 9.9\%, and Zeryehun and Abera [13], $10 \%$, in Ethiopia. However, they were lower than findings by Amer et al. [18] in Japan, who reported a prevalence of $12 \%$, Tolosa et al. [38] and Mekibib et al. [40] in Ethiopia, and Levison et al. [41] in Canada, who reported prevalence of $12 \%, 11 \%, 22.7 \%$, and $23 \%$, respectively. In contrast, our results were higher than the prevalence reported by Gitau et al. [3] and Gao et al. [17], who reported prevalence of 0.5 and $0.9 \%$ in a different part of Kenya, and $3.3 \%$ in China, respectively.

Subclinical mastitis in this study was about $74 \%$. These findings were in agreement with studies by Abebe et al. [2], $76 \%$ in Ethiopia, and Ndahetuye et al. [14], 76.2\% in Rwanda. Our findings were higher than the results reported by Mureithi and Njuguna [28], 64\% in Thika, Kenya, and Gitau et al. [3], 49.6\% and 58.7\%, in Nyeri and Nakuru, Kenya, and as reported elsewhere by [21, 42]. However, this study's findings were lower than the findings by Ondiek and Kemboi [29], 82.9\%, Egerton, Kenya, and Tolosa et al. [38], $85 \%$ in Ethiopia. Previous studies have shown that mastitis differs from one country to country and between farms and cows [4]. This remarkable variability in prevalence in clinical and subclinical mastitis could be attributed to ineffective mastitis control programs, environmental factors, and poor hygiene standards in the study areas $[15,16,42,43]$.

This study reported a higher prevalence of subclinical mastitis $(74 \%)$ than clinical (7\%) mastitis. These findings agree with other studies by Zeryehun and Abera [13] and as reported elsewhere by $[3,39]$. These significant differences could be attributed to the fact that clinical mastitis can easily be diagnosed and treated [4], whereas, on the other hand, the subclinical form has no physical abnormalities; hence, it is hardly diagnosed by the farmers and continues to be a source of infection in the farm $[2,43]$. In addition, ineffective mastitis control programs and poor hygiene standards in the study areas could have been a key contributor [15]. Therefore, there is a need for implementation of continued mastitis monitoring and control programs in the study areas such as the creation of awareness on subclinical mastitis and possible risk factors.

In the present study, Embu County had a significantly higher cow and quarter-level prevalence of mastitis compared to Kajiado. This high prevalence in Embu County may be associated with poor hygiene and the wet weather experienced (March-June 2019) during the sampling period. Similar findings were found in Bangladesh, where higher prevalence of mastitis was reported during wet seasons [44]. Moreover, in Embu County, cows stayed in dirty bedding and poorly drained houses. FAO [1] reported that poor drainage and dirty beddings were associated with high contamination with environmental mastitis pathogens. The authors recommend urgency to implement hygiene measures for successful control of mastitis in the region.

The current study reported coagulase-negative Staphylococcus (CNS) as the most predominant bacteria in both clinical and subclinical mastitis. These findings agree with studies from different countries globally, which have reported CNS as emerging bacteria of mastitis $[14,16,18,23,45,46]$. However, the results contrasted with finding by Gitau et al. [3], Mureithi and Njuguna, [28], and Ondiek and Kemboi [29], all in Kenya who reported Staphylococcus aureus as the dominant mastitis pathogen. The present results show that CNS, which was initially classified as a minor pathogen of mastitis, is emerging as an important mastitis pathogen in the Kenyan dairy cows. This transition from Staphylococcus aureus to CNS may imply the need to revise control procedures. The high prevalence of CNS in this study might be explained by the fact that the bacterium which is a normal flora of the skin, could be originating from milker's hands or cow skin during milking [23, 25]. Also, studies have shown that CNS can originate from the cow's environment [22, 47]. However, further studies will be 
TABLE 3: Distribution of farm management practices and cow factors associated with mastitis in 395 dairy cows in Kajiado and Embu counties.

\begin{tabular}{|c|c|c|}
\hline Variable & Group description & Mastitis positive cases (\%) \\
\hline \multirow{2}{*}{ (1) County } & Kajiado $(n=206)$ & $144(49)$ \\
\hline & Embu $(n=189)$ & $150(51)$ \\
\hline \multirow{2}{*}{ (2) Production system } & Semi-intensive $(n=73)$ & $48(16.3)$ \\
\hline & Intensive $(n=322)$ & $246(83.7)$ \\
\hline \multirow{2}{*}{ (3) Housed with a roof } & Yes $(n=388)$ & $290(98.6)$ \\
\hline & No $(n=7)$ & $4(1.4)$ \\
\hline \multirow{2}{*}{ (4) Floor type } & Concrete $(n=305)$ & $224(76.2)$ \\
\hline & Earthen $(n=90)$ & $70(23.8)$ \\
\hline \multirow{2}{*}{ (5) Bedding material } & Yes $(n=123)$ & $83(28.2)$ \\
\hline & No $(n=272)$ & $211(71.8)$ \\
\hline \multirow{2}{*}{ (6) Cleaning of floor } & Daily $(n=298)$ & $216(73.5)$ \\
\hline & Weekly $(n=97)$ & $78(26.5)$ \\
\hline \multirow{2}{*}{ (7) Milking the cows last } & Yes (107) & $64(21.8)$ \\
\hline & No $(288)$ & $230(78.2)$ \\
\hline \multirow{2}{*}{ (8) Proper milking technique } & Yes (387) & $7(2.4)$ \\
\hline & No (8) & $287(97.6)$ \\
\hline \multirow{2}{*}{ (9) Use of clean udder drying towel } & Yes (375) & $278(94.6)$ \\
\hline & No (20) & $16(5.4)$ \\
\hline \multirow{2}{*}{ (10) Use of clean udder drying towel for each cow } & Yes $(n=165)$ & $106(36.1)$ \\
\hline & No $(n=230)$ & $188(63.9)$ \\
\hline \multirow{2}{*}{ (11) Washing hands between milkings } & Yes $(n=171)$ & $113(38.4)$ \\
\hline & No $(n=224)$ & $181(61.6)$ \\
\hline \multirow{2}{*}{ (12) Use of teat dips } & Yes $(n=52)$ & $31(10.5)$ \\
\hline & No (343) & $263(89.5)$ \\
\hline \multirow{2}{*}{ (13) Dry therapy } & Yes (94) & $66(22.4)$ \\
\hline & No (301) & $228(77.6)$ \\
\hline \multirow{2}{*}{ (14) Culling } & Yes $(n=77)$ & $55(18.7)$ \\
\hline & No $(n=318)$ & $239(81.3)$ \\
\hline \multirow{2}{*}{ (15) Test for mastitis } & Yes (249) & $177(60.2)$ \\
\hline & No (146) & $117(39.8)$ \\
\hline \multirow{2}{*}{ (16) Breed } & Cross $(n=26)$ & $16(5.4)$ \\
\hline & Exotic $(n=369)$ & $278(94.6)$ \\
\hline \multirow{5}{*}{ (17) Parity } & $1(n=102)$ & $68(23.1)$ \\
\hline & $2(n=99)$ & $75(25.5)$ \\
\hline & $3(n=94)$ & $72(24.5)$ \\
\hline & $>4(n=100)$ & $79(26.9)$ \\
\hline & Early (1-2 months) $(n=106)$ & $85(28.9)$ \\
\hline \multirow[t]{2}{*}{ (18) Stage of lactation } & Mid (3-6 months) $(n=134)$ & $94(32)$ \\
\hline & Late $>7$ months $(n=155)$ & $115(39.1)$ \\
\hline \multirow[t]{2}{*}{ (19) History of mastitis } & Yes $(n=237)$ & $167(56.8)$ \\
\hline & No $(n=158)$ & $127(43.2)$ \\
\hline
\end{tabular}

necessary for Kenya to investigate the epidemiology and the specific pathogenic species involved in CNS mastitis.

Streptococcal mastitis reported in this study was $22.2 \%$. These findings were comparable to studies by Birhanu et al. [48], Gitau et al. [3], and Kalmus et al. [49], who reported a prevalence of $22 \%, 20.6 \%$, and $18 \%$ respectively. However, the findings were lower than reports by Vakkamäki [24], Amer et al. [18], Ndahetuye et al. [15], and Mekibib et al. [40] who reported prevalence of $14 \%, 9 \%, 1.4 \%$, and $5.5 \%$ respectively. This high prevalence of environmental Streptococcus in this study could possibly be due to udder contamination from the cow's environment or the water source [18].

Furthermore, Bacillus species was reported in this study at a prevalence of $7.6 \%$. To the best of our knowledge, this was the first time Bacillus spp. was isolated in mastitis in
Kenyan dairy. Other studies have reported that Bacillus spp. as an important pathogen of mastitis $[50,51]$. Our findings sharply contrasted with what was reported by Amer et al. [18] in Japan, 22\%. However, our results were higher than by Mekibib et al. [40], Zeryehun and Abera [13], and Fisseha et al. [52], in Ethiopia who reported prevalence of $1.3 \%$, $2.7 \%$, and $4.2 \%$, respectively. The presence of Bacillus spp. in our findings could be due to environmental contamination of the udder by mud or manure $[50,51]$. Therefore, improving environmental hygiene, milking hygiene, and the use of teat sealants could reduce infections [53].

In this study, the prevalence of Bacillus spp. and Escherichia coli was significantly higher in Embu County compared to Kajiado. Studies elsewhere have shown that such differences are commonly linked to geographic variations [26, 54]. 
TABLE 4: Univariate logistic regression analysis between different risk factors and cow-level mastitis (defined as culture positive) in 395 dairy cows in Embu and Kajiado counties.

\begin{tabular}{|c|c|c|c|c|c|c|}
\hline \multirow{2}{*}{ Variable } & \multirow{2}{*}{ Number examined, $n=395$} & \multicolumn{2}{|c|}{ Mastitis culture results (\%) } & \multicolumn{2}{|c|}{$95 \% \mathrm{CI}$} & \multirow{2}{*}{$p$ value } \\
\hline & & Negative (\%) & Positive (\%) & Lower & Upper & \\
\hline \multicolumn{7}{|l|}{ County } \\
\hline Kajiado & 206 & $62(30.1)$ & $144(69.9)$ & & & \\
\hline Embu & 189 & $39(20.6)$ & $150(79.4)$ & 1.044 & 2.626 & $0.032^{*}$ \\
\hline \multicolumn{7}{|l|}{ Production system } \\
\hline Semi-intensive & 73 & $25(34.2)$ & $48(65.8)$ & & & \\
\hline Intensive & 322 & $76(23.6)$ & $246(76.4)$ & 0.975 & 2.915 & 0.062 \\
\hline \multicolumn{7}{|l|}{ Housed } \\
\hline No & 7 & $3(42.9)$ & $4(57.1)$ & & & \\
\hline Yes & 388 & $98(25.3)$ & $290(74.7)$ & 0.488 & 10.091 & 0.302 \\
\hline \multicolumn{7}{|l|}{ Floor type } \\
\hline Concrete & 305 & $81(26.6)$ & $224(73.4)$ & & & \\
\hline Earthen & 90 & $20(22.2)$ & $70(77.8)$ & 0.724 & 2.212 & 0.408 \\
\hline \multicolumn{7}{|l|}{ Bedding } \\
\hline Yes & 123 & $40(32.5)$ & $83(67.5)$ & & & \\
\hline No & 272 & $61(22.4)$ & $211(77.6)$ & 1.039 & 2.675 & $0.034^{*}$ \\
\hline \multicolumn{7}{|l|}{ Cleaning of floors } \\
\hline Daily & 298 & $82(27.5)$ & $216(72.5)$ & & & \\
\hline Weekly & 97 & $19(19.6)$ & $78(80.4)$ & 0.888 & 2.734 & 0.122 \\
\hline \multicolumn{7}{|c|}{ Milking the cows last } \\
\hline Yes & 107 & $43(40.2)$ & $64(59.8)$ & & & \\
\hline No & 288 & $58(20.1)$ & $230(79.9)$ & 1.645 & 4.314 & $0.001^{*}$ \\
\hline \multicolumn{7}{|c|}{ Proper milking technique } \\
\hline Yes & 387 & $100(25.8)$ & $287(74.2)$ & & & \\
\hline No & 8 & $1(12.5)$ & $7(87.5)$ & 0.296 & 20.07 & 0.407 \\
\hline \multicolumn{7}{|l|}{ Drying towel } \\
\hline Yes & 375 & $97(25.9)$ & $278(74.1)$ & & & \\
\hline No & 20 & $4(20)$ & $16(80)$ & 0.455 & 4.277 & 0.560 \\
\hline \multicolumn{7}{|c|}{ Towel for each cow } \\
\hline Yes & 165 & $59(35.8)$ & $106(64.2)$ & & & \\
\hline No & 230 & $42(18.3)$ & $188(81.7)$ & 1.570 & 3.954 & $0.001^{*}$ \\
\hline Washing hands be & & & & & & \\
\hline Yes & 171 & $58(33.9)$ & $113(66.1)$ & & & \\
\hline No & 224 & $43(19.2)$ & $181(80.8)$ & 1.365 & 3.419 & $0.001^{*}$ \\
\hline Teat dips & & & & & & \\
\hline Yes & 52 & $21(40.4)$ & $31(59.6)$ & & & \\
\hline No & 343 & $80(23.3)$ & $263(76.7)$ & 1.213 & 4.09 & $0.01^{*}$ \\
\hline Dry therapy & & & & & & \\
\hline Yes & 94 & $28(29.8)$ & $66(70.2)$ & & & \\
\hline No & 301 & $73(24.3)$ & $228(75.7)$ & 0.792 & 2.217 & 0.284 \\
\hline Culling & & & & & & \\
\hline Yes & 77 & $22(28.6)$ & $55(71.4)$ & & & \\
\hline No & 318 & $79(24.8)$ & $239(75.2)$ & 0.694 & 2.11 & 0.501 \\
\hline Test for mastitis & & & & & & \\
\hline No & 249 & $72(28.9)$ & $177(71.1)$ & & & \\
\hline Yes & 146 & $29(19.9)$ & $117(80.1)$ & 1.005 & 2.68 & $0.048^{*}$ \\
\hline Breed & & & & & & \\
\hline Crosses & 26 & $10(38.5)$ & $16(61.5)$ & & & \\
\hline Exotic & 369 & $91(24.7)$ & $278(75.3)$ & 0.230 & 1.195 & 0.124 \\
\hline Parity & & & & & & \\
\hline 1 & 102 & $34(33.3)$ & $68(66.7)$ & & & \\
\hline 2 & 99 & $24(24.2)$ & $75(75.8)$ & 0.843 & 2.896 & 0.156 \\
\hline 3 & 94 & $22(23.4)$ & $72(76.6)$ & 0.401 & 3.074 & 0.126 \\
\hline $4+$ & 100 & $21(21)$ & $79(79)$ & 0.416 & 3.543 & $0.05^{*}$ \\
\hline Stage of lactation & & & & & & \\
\hline Early & 106 & $21(19.8)$ & $85(80.2)$ & & & \\
\hline Mid & 134 & $40(29.9)$ & $94(70.1)$ & 1 & 2.050 & 0.444 \\
\hline Late & 155 & $40(25.8)$ & $115(74.2)$ & 1.223 & 3.152 & 0.078 \\
\hline History of mastiti & & & & & & \\
\hline No & 237 & $70(29.5)$ & $167(70.5)$ & & & \\
\hline Yes & 158 & $31(19.6)$ & $127(80.4)$ & 1.061 & 2.78 & $0.028^{*}$ \\
\hline
\end{tabular}

*Factors significant at $p<0.05$; CI: confidence interval. 
TABLE 5: Multivariable logistic regression analysis between different risk factors and cow-level mastitis (defined as culture positive) in 395 dairy cows in Embu and Kajiado counties.

\begin{tabular}{|c|c|c|c|c|c|}
\hline \multirow{2}{*}{ Variable } & \multirow{2}{*}{ Category (yes/no) } & \multirow{2}{*}{ OR } & \multicolumn{2}{|c|}{$95 \% \mathrm{CI}$} & \multirow{2}{*}{$p$ value } \\
\hline & & & Lower & Upper & \\
\hline \multirow{2}{*}{ Milking mastitic cows last } & Yes & 1 & & & \\
\hline & No & 2.264 & 1.645 & 4.314 & $0.002^{*}$ \\
\hline \multirow{2}{*}{ Towel for each cow } & Yes & 1 & & & \\
\hline & No & 2.491 & 1.57 & 3.954 & $0.033^{*}$ \\
\hline \multirow{2}{*}{ Use of teat dips } & Yes & 1 & & & \\
\hline & No & 2.227 & 1.213 & 4.09 & 0.368 \\
\hline \multirow{2}{*}{ History of mastitis } & No & 1 & & & \\
\hline & Yes & 1.717 & 1.061 & 2.78 & $0.046^{*}$ \\
\hline \multirow{2}{*}{ Test for mastitis } & No & 1 & & & \\
\hline & Yes & 1.641 & 1.005 & 2.68 & 0.11 \\
\hline \multirow{2}{*}{ Washing hands between milkings } & Yes & 1 & & & \\
\hline & No & 2.161 & 1.365 & 3.419 & 0.641 \\
\hline \multirow{2}{*}{ County } & Kajiado & 1 & & & \\
\hline & Embu & 1.656 & 1.044 & 2.626 & 0.817 \\
\hline
\end{tabular}

${ }^{*}$ Factors statistically significant at $p \leq 0.05$; $\mathrm{OR}=$ odds ratio; $\mathrm{CI}$ : confidence interval.

No growth was reported in $23.7 \%$ of the clinical and subclinical mastitis cases. Similar results were reported by Levison et al. [41], Canada, 23\%. However, these findings were lower than what was reported by Richards [30], 37.5\% in a recent study in Kenya, but higher than reported by Gitau et al. [3], 10.4\% in Kenya. These findings could be due to limitations of the culture methods, low level of bacteria in milk, cow pretreated with antibiotics, and causative agents of mastitis not bacteria [55].

This study revealed that farms which did not milk mastitic cows last were more likely to have mastitis than the farms where mastitic cows were milked last. These findings were in agreement with the reports by Abebe et al. [2], in Ethiopia, and Nielsen and Emanuelson [56], in Sweden. They reported that failure to milk mastitic cows last increased the spread of mastitis in farms from one cow to another during milking. These findings may explain the reason for high farm-level prevalence in this study since all farmers used hand milking. Farmers need to be educated on the importance of knowing the cow's udder health status and encouraged to milk mastitic cows last to prevent the spread of mastitis [56].

In this study, cows with a previous history of mastitis were more likely to have mastitis again compared to cows with no previous history of mastitis. A similar finding was reported by Mekonnen et al. [57] in Ethiopia, Kumar et al. [58] in India, and Oliveira et al. [59] in Brazil. However, it contrasted with findings by Abebe et al. [2], Ethiopia, who did not find any association between history of mastitis and future occurrence of mastitis. In our study, inadequate screening and treatment of subclinical mastitis, lack of correct, and specific identification of the mastitis pathogens in clinical cases may have led to the recurrence of mastitis. In addition, indiscriminate use of antibiotics by farmers leading to the development of mastitis resistance pathogens was believed to be a critical contributor for the recurrence of mastitis in this current study (unpublished data). Certainly, such cows need to be culled to prevent further transmission of mastitis in the farms $[12,58]$.
Farms that did not use an udder drying towel for each cow had significantly higher mastitis than farms that used a drying towel for each cow. This agrees with finding by Abebe et al. [2] and Mekonnen et al. [57] both from Ethiopia who reported that the use of the same drying towel for the herd was responsible for spreading mastitis pathogens. This may explain the high prevalence of Staphylococcus species reported in this study. Since these organisms are part of the normal flora of the udder and the teats, they can easily be spread through the use of the same drying towel during milking [22, 47].

\section{Conclusion}

The current study reported a high prevalence of subclinical mastitis. Coagulase-negative Staphylococcus (CNS) was the predominant mastitis pathogen. Based on the high prevalence of mastitis and CNS, we advise routine monitoring of this emerging pathogens of mastitis, and control measures should be applied in the affected farms. In addition, this study reported some key mastitis risk factors such as previous history of mastitis, using a clean udder drying towel for each cow, and milking mastitic cows last. These factors should be adopted in mastitis control programs in the regions.

\section{Recommendation}

Further studies need to be undertaken to determine the epidemiology of CNS mastitis and circulating species in the study regions. This study was carried out during a rainy season; further studies should be done to assess the role of seasonality in the occurrence of mastitis in Kenya.

\section{Data Availability}

Data associated with this research article are available upon request to the corresponding author. 


\section{Conflicts of Interest}

The authors declare that they have no conflicts of interest.

\section{Acknowledgments}

This research was supported by the Consortium for Advanced Research Training in Africa (CARTA). The CARTA is jointly led by the African Population and Health Research Center and the University of the Witwatersrand and funded by the Carnegie Corporation of New York (grant no. B 8606.R02), Sida (grant no. 54100113), the DELTAS Africa Initiative (grant no. 107768/Z/15/Z), and Deutscher Akademischer Austauschdienst (DAAD). The DELTAS Africa Initiative is an independent funding scheme of the African Academy of Sciences (AAS)'s Alliance for Accelerating Excellence in Science in Africa (AESA) and supported by the New Partnership for Africa's Development Planning and Coordinating Agency (NEPAD Agency) with funding from the Wellcome Trust (UK) and the UK Government.

\section{Supplementary Materials}

A questionnaire (submitted as a supplementary file) was used to evaluate the risk factors associated with occurrence of mastitis in dairy cows, in Embu and Kajiado counties, Kenya. (Supplementary Materials)

\section{References}

[1] Food and Agriculture Organization, "Impact of mastitis in small scale dairy production systems," Animal Production and Health Working Paper, No. 13, Rome, Italy, 2014.

[2] R. Abebe, H. Hatiya, M. Abera, B. Megersa, and K. Asmare, "Bovine mastitis: prevalence, risk factors and isolation of Staphylococcus aureus in dairy herds at Hawassa milk shed, South Ethiopia," BMC Veterinary Research, vol. 12, no. 1, 2016.

[3] G. K. Gitau, R. M. Bundi, J. Vanleeuwen, and C. M. Mulei, "Mastitogenic bacteria isolated from dairy cows in Kenya and their antimicrobial sensitivity," Journal of the South African Veterinary Association, vol. 85, no. 1, pp. 1-8, 2014.

[4] T. E. Motaung, K. R. Petrovski, I.-M. Petzer, O. Thekisoe, and T. J. Tsilo, "Importance of bovine mastitis in Africa," Animal Health Research Reviews, vol. 18, no. 1, pp. 58-69, 2017.

[5] M. Pol and P. L. Ruegg, "Relationship between antimicrobial drug usage and antimicrobial susceptibility of gram-positive mastitis pathogens," Journal of Dairy Science, vol. 90, no. 1, pp. 262-273, 2007.

[6] C. Nielsen, Economic impact of mastitis in dairy cows, Ph.D. thesis, Swedish University of Agricultural Sciences, Uppsala, Sweden, 2009.

[7] S. P. Oliver, S. E. Murinda, and B. M. Jayarao, "Impact of antibiotic use in adult dairy cows on antimicrobial resistance of veterinary and human pathogens: a comprehensive review," Foodborne Pathogens and Disease, vol. 8, no. 3, pp. 337-355, 2011.

[8] T. Beyene, H. Hayishe, F. Gizaw et al., "Prevalence and antimicrobial resistance profile of Staphylococcus in dairy farms, abattoir, and humans in Addis Ababa, Ethiopia," BMC Research Notes, vol. 10, no. 1, pp. 1-9, 2017.
[9] P. L. Ruegg, “A 100-year review: mastitis detection, management, and prevention," Journal of Dairy Science, vol. 100, no. 12, pp. 10381-10397, 2017.

[10] S. Taponen, E. Liski, A.-M. Heikkilä, and S. Pyörälä, "Factors associated with intramammary infection in dairy cows caused by coagulase-negative staphylococci, Staphylococcus aureus, Streptococcus uberis, Streptococcus dysgalactiae, Corynebacterium bovis, or Escherichia coli," Journal of Dairy Science, vol. 100, no. 1, pp. 493-503, 2017.

[11] O. Radostits, C. Gay, D. Blood, and K. Hinchcliff, A Text Book of the Disease of Cattle, Sheep, Pigs, Goats and Horses, W.B. Sounders Company Ltd, New York, NY, USA, 9th edition, 1973.

[12] H. Jamali, H. W. Barkema, M. Jacques et al., "Invited review: incidence, risk factors, and effects of clinical mastitis recurrence in dairy cows," Journal of Dairy Science, vol. 101, no. 6, pp. 4729-4746, 2018.

[13] T. Zeryehun and G. Abera, "Prevalence and bacterial isolates of mastitis in dairy farms in selected districts of Eastern Harrarghe zone, Eastern Ethiopia," Journal of Veterinary Medicine, vol. 2017, Article ID 6498618, 7 pages, 2017.

[14] J. B. Ndahetuye, Y. Persson, A.-K. Nyman, M. Tukei, M. P. Ongol, and R. Båge, "Aetiology and prevalence of subclinical mastitis in dairy herds in peri-urban areas of Kigali in Rwanda," Tropical Animal Health and Production, vol. 51, no. 7, pp. 2037-2044, 2019.

[15] M. Abrahmsén, Y. Persson, B. M. Kanyima, and R. Båge, "Prevalence of subclinical mastitis in dairy farms in urban and peri-urban areas of Kampala, Uganda," Tropical Animal Health and Production, vol. 46, no. 1, pp. 99-105, 2014.

[16] J. Verbeke, S. Piepers, K. De Vliegher, and S. D. Vliegher, "Pathogen-specific incidence rate of clinical mastitis in Flemish dairy herds, severity, and association with herd hygiene," Journal of Dairy Science, vol. 97, no. 11, pp. 6926-6934, 2014.

[17] J. Gao, H. W. Barkema, L. Zhang et al., "Incidence of clinical mastitis and distribution of pathogens on large Chinese dairy farms," Journal of Dairy Science, vol. 100, no. 6, pp. 47974806, 2017.

[18] S. Amer, F. L. A. Gálvez, Y. Fukuda et al., "Prevalence and etiology of mastitis in dairy cattle in El Oro Province, Ecuador," Journal of Veterinary Medical Science, vol. 80, no. 6, pp. 861-868, 2018.

[19] A. J. Bradley, K. A. Leach, J. E. Breen, L. E. Green, and M. J. Green, "Survey of the incidence and aetiology of mastitis on dairy farms in England and Wales," Veterinary Record, vol. 160, no. 8, pp. 253-258, 2007.

[20] R. N. Zadoks and J. L. Fitzpatrick, "Changing trends in mastitis," Irish Veterinary Journal, vol. 62, no. 4, pp. 59-70, 2009.

[21] J. P. Mpatswenumugabo, L. C. Bebora, G. C. Gitao et al., "Prevalence of subclinical mastitis and distribution of pathogens in dairy farms of Rubavu and Nyabihu districts, Rwanda," Journal of Veterinary Medicine, vol. 2017, Article ID 8456713, 8 pages, 2017.

[22] J. K. El-jakee, N. E. Aref, A. Gomaa et al., "Emerging of coagulase negative staphylococci as a cause of mastitis in dairy animals: an environmental hazard," International Journal of Veterinary Science and Medicine, vol. 1, no. 2, pp. 74-78, 2019.

[23] V. Piessens, E. Van Coillie, B. Verbist et al., "Distribution of coagulase-negative Staphylococcus species from milk and 
environment of dairy cows differs between herds," Journal of Dairy Science, vol. 94, no. 6, pp. 2933-2944, 2011.

[24] J. Vakkamäki, S. Taponen, A. M. Heikkilä, and S. Pyörälä, "Bacteriological etiology and treatment of mastitis in Finnish dairy herds," Acta Veterinaria Scandinavica, vol. 59, no. 1, 2017.

[25] B.-M. Thorberg, M.-L. Emanuelson, and K. Persson Waller, "Bovine subclinical mastitis caused by different types of coagulase-negative staphylococci," Journal of Dairy Science, vol. 92, no. 10, pp. 4962-4970, 2009.

[26] Y. Bi, Y. J. Wang, Y. Qin, R. G. Vallverdú, and J. M. García, "Prevalence of bovine mastitis pathogens in bulk tank milk in China," PLoS One, vol. 11, Article ID e0155621, no. 5, pp. 1-13, 2016.

[27] T. S. Suleiman, E. D. Karimuribo, and R. H. Mdegela, "Prevalence of bovine subclinical mastitis and antibiotic susceptibility patterns of major mastitis pathogens isolated in Unguja island of Zanzibar, Tanzania," Tropical Animal Health and Production, vol. 50, no. 2, pp. 259-266, 2018.

[28] D. K. Mureithi and M. N. Njuguna, "Prevalence of subclinical mastitis and associated risk factors in dairy farms in urban and peri-urban areas of Thika Sub county, Kenya," Livestock Research for Rural Development, vol. 28, no. 13, 2016.

[29] J. O. Ondiek and F. Kemboi, "Bovine mastitis prevalence, aetiology, therapeutics and control in Tatton Agriculture Park, Egerton University," International Journal of Current Microbiology and Applied Sciences, vol. 7, no. 9, pp. 34173426, 2018.

[30] S. Richards, J. Vanleeuwen, S. G. Peter et al., "Impact of mineral feeding on reproductive efficiency on smallholder dairy farms in Kenya," Livestock Research for Rural Development, vol. 31, no. 80, 2019.

[31] C. Sharma, N. Rokana, M. Chandra et al., "Antimicrobial resistance: its surveillance, impact, and alternative management strategies in dairy animals," Frontiers in Veterinary Science, vol. 4, pp. 1-27, 2018.

[32] Food and Agriculture Organization, Dairy Development in Kenya, H. G. Muriuki, Ed., 2011, http://www.fao.org/3/aal745e.pdf.

[33] Food and Agriculture Organization, Africa Sustainable Livestock 2050, http://www.fao.org/3/a-i7222e.pdf, 2017.

[34] Independent Electoral Boundaries Commission, https://www. iebc.or.ke/uploads/resources/euzA6oIPCd.pdf, 2012.

[35] M. Thrusfield, Veterinary Epidemiology, Black Well Science Ltd., Oxford, UK, 3rd edition, 2005.

[36] O. W. Schalm, E. J. Coroll, and N. C. Jain, Bovine Mastitis, Lea \& Febiger, Philadelphia, PA, USA, 1971.

[37] National Mastitis Council (NMC), Laboratory Handbook on Bovine Mastitis, Rev. ed. National Mastitis Council Inc., New Prague, MN, USA, 2017.

[38] T. Tolosa, J. Verbeke, Z. Ayana, S. Piepers, K. Supré, and S. De Vliegher, "Pathogen group specific risk factors for clinical mastitis, intramammary infection and blind quarters at the herd, cow and quarter level in smallholder dairy farms in Jimma, Ethiopia," Preventive Veterinary Medicine, vol. 120, no. 3-4, pp. 306-312, 2015.

[39] E. J. Sarba and G. K. Tola, "Cross-sectional study on bovine mastitis and its associated risk factors in Ambo district of West Shewa zone, Oromia, Ethiopia," Veterinary World, vol. 10, no. 4, pp. 398-402, 2016.

[40] B. Mekibib, M. Furgasa, F. Abunna, B. Megersa, and A. Regassa, "Bovine mastitis: prevalence, risk factors and major pathogens in dairy farms of Holeta town, Central Ethiopia," Veterinary World, vol. 3, no. 9, pp. 397-403, 2010.
[41] L. J. Levison, A. L. Tucker, R. Bergeron, K. E. Leslie, and H. W. Barkema, "Incidence rate of pathogen-specific clinical mastitis on conventional and organic Canadian dairy farms," Journal of Dairy Science, vol. 99, no. 2, pp. 1341-1350, 2016.

[42] A. Bihon, A. Syoum, and A. Assefa, "Assessment of risk factors and isolation of Staphylococcus aureus and Escherichia coli from bovine subclinical mastitic milk in and around Gondar, Northwest Ethiopia," Tropical Animal Health and Production, vol. 51, no. 4, pp. 939-948, 2019.

[43] A. Ismael, "Epidemiology of bovine mastitis in Ethiopia," Journal of Veterinary Medicine, vol. 2, no. 1, pp. 1-7, 2018.

[44] M. A. Rahman, M. M. U. Bhuiyan, M. M. Kamal, and M. Shamsuddin, "Prevalence and risk factors of mastitis in dairy cows," Bangladesh Veterinarian, vol. 26, no. 2, pp. 54-60, 2009.

[45] R. H. Mdegela, R. Ryoba, E. D. Karimuribo, and E. C. J. Phiri, "Prevalence of clinical and subclinical mastitis and quality of milk on smallholder dairy farms in Tanzania," Journal of the South African Veterinary Association, vol. 80, no. 3, pp. 163-168, 2009.

[46] F. L. Yang, C. Shen, B. X. He, Y. Y. Yang, D. C. Gong, and X. S. Li, "The prevalence of heifer mastitis and its associated risk factors in Huanggang, Central China," Tropical Animal Health and Production, vol. 47, no. 1, pp. 87-92, 2014.

[47] P. Krishnamoo, M. L. Satyanaray, and B. R. Shome, "Coagulase negative staphylococcal species mastitis: an overview," Research Journal of Veterinary Sciences, vol. 9, no. 1, pp. 1-10, 2016.

[48] M. Birhanu, S. Leta, G. Mamo, and S. Tesfaye, "Prevalence of bovine subclinical mastitis and isolation of its major causes in Bishoftu," BMC Research Notes, vol. 10, no. 1, 2017.

[49] P. Kalmus, B. Aasmäe, A. Kärssin, T. Orro, and K. Kask, "Udder pathogens and their resistance to antimicrobial agents in dairy cows in Estonia," Acta Veterinaria Scandinavica, vol. 53, no. 1, p. 4, 2011.

[50] T. J. Parkinson, M. Merrall, and S. G. Fenwick, "A case of bovine mastitis caused by Bacillus cereus," New Zealand Veterinary Journal, vol. 47, no. 4, pp. 151-152, 1999.

[51] O. S. Sadashiv and B. B. Kaliwal, "Isolation, characterization and antibiotic resistance of Bacillus sps. from bovine mastitis in the region of north Karnataka," India International Journal of Current Microbiology Applied Science, vol. 3, no. 4, pp. 360-373, 2014.

[52] D. Fisseha, T. S. Tessema, and B. Birhanu, "Aerobic bacterial isolates, incidence rate and associated risk factors of heifer and cow mastitis in and around Debre-Libanos district, Oromia, Ethiopia," Journal of Veterinary Medicine And Health, vol. 12, pp. 7-13, 2020.

[53] V. Kromker, F. Reinecke, J. Paduch, and N. Grabowski, "Bovine Streptococcus uberis intramammary infections and mastitis," Clinical Microbiology, vol. 3, no. 4, 2014.

[54] R. Riekerink, H. W. Barkema, D. F. Kelton, and D. T. Scholl, "Incidence rate of clinical mastitis on Canadian dairy farms," Journal of Dairy Science, vol. 91, no. 4, pp. 1366-1377, 2008.

[55] J. S. Kuehn, P. J. Gorden, D. Munro et al., "Bacterial community Profiling of milk samples as a means to understand culture-negative bovine clinical mastitis," PLoS One, vol. 8, no. 4, Article ID e61959, 2013.

[56] C. Nielsien and U. Emanuelson, "Mastitis control in Swedish dairy herds," Journal of Dairy Science, vol. 96, no. 11, pp. 6883-6893, 2013.

[57] S. A. Mekonnen, G. Koop, S. T. Melkie, C. D. Getahun, H. Hogeveen, and T. J. G. M. Lam, "Prevalence of subclinical mastitis and associated risk factors at cow and herd level in dairy farms in North-West Ethiopia," Preventive Veterinary Medicine, vol. 145, pp. 23-31, 2017. 
[58] N. Kumar, A. Manimaran, A. Kumaresan et al., "Episodes of clinical mastitis and its relationship with duration of treatment and seasonality in crossbred cows maintained in organized dairy farm," Veterinary World, vol. 9, no. 1, pp. 75-79, 2016.

[59] C. S. F. Oliveira, H. Hogeveen, A. M. Botelho, P. V. Maia, S. G. Coelho, and J. P. A. Haddad, "Cow-specific risk factors for clinical mastitis in Brazilian dairy cattle," Preventive Veterinary Medicine, vol. 121, no. 3-4, pp. 297-305, 2015. 